\title{
Physical and chemical characteristics of thermal springs in the Waterberg area in Limpopo Province, South Africa
}

\author{
J Olivier ${ }^{1 *}$, HJ van Niekerk ${ }^{1}$ and IJ van der Walt ${ }^{2}$ \\ 1 Department of Environmental Sciences, PO Box 392, Unisa 0003, South Africa \\ ${ }^{2}$ Department of Geography and Environmental Studies, North-West University, Potchefstroom 2531, South Africa
}

\begin{abstract}
The Limpopo Province in South Africa is richly endowed with thermal springs. Some have been developed for recreational, tourism or other purposes, while a number remain completely undeveloped. If the full economic potential of springs can be realised in a sustainable manner, they could make a substantial contribution to the local or even regional economy. The optimal use of a thermal spring is largely dependent upon its physical and chemical characteristics. This article focuses on the temperature and chemical features of 8 selected thermal springs located in the southern (Waterberg) region of the Limpopo Province, namely Warmbaths, Loubad, Vischgat, Die Oog, Rhemardo, Lekkerrus, Libertas and Buffelshoek. All of these springs are of meteoric origin, with water temperatures ranging from $30^{\circ} \mathrm{C}$ to $52^{\circ} \mathrm{C}$. The mineral composition of the thermal waters reflects the geological formations found at the depth of origin. Changes in land use that occurred over the past few decades have apparently had no impact on the physical and chemical properties of the thermal spring waters. This effect may, however, become evident at a later stage due to a time lag in the migration of contaminants. The fluoride concentration of water from seven of the eight springs (all except Loubad) does not conform to domestic water quality guidelines and makes the water unfit for human consumption. Unacceptably high values of mercury were detected at Libertas. It is recommended that strict monitoring of the concentration of fluoride and other potentially harmful elements should be mandatory whenever the thermal spring water is used for bottling, domestic or full-contact recreational purposes.
\end{abstract}

Keywords: thermal springs, Limpopo Province, water temperature, chemical composition, trace elements

\section{Introduction}

Hot water issuing from the earth's surface has been a subject of awe since the dawn of humankind. Ancient civilizations revered thermal springs because they were believed to have supernatural and healing powers (LaMoreaux and Tanner, 2001). Archaeological evidence also shows that thermal springs were used as bathing facilities in the ancient city of Mohenjo-Daro in India from before $2000 \mathrm{BC}$, the royal palaces of Knossos in Crete built between 1700 and $1400 \mathrm{BC}$, and the Egyptian royal city of Tall al 'Amarinah that was built about 1350 BC. During the Western Zhou Dynasty $\left(11^{\text {th }}\right.$ Century -711 BC), Emperor Xuanzong built a palace at the Huaqing Hot Spring near the city of Xian in China. This is still functioning as a major tourist resort. Islamic societies in Europe and the Middle East, the Turks and the Japanese also created bathing facilities in places where there were hot springs (Encarta Encyclopaedia, 1997). Many thermal springs developed into flourishing centres of religion, culture and health such as those at Bath in England, Vichy in France, Baden-Baden in Germany and Saratoga Springs in the USA, but their socio-economic importance fluctuated over time (Booyens, 1981; Sanner, 2000; Edmunds, 2004).

The past few decades have witnessed an unprecedented resurgence of interest in thermal springs, mostly due to a diversification in their utilisation (Christopher and Armstead, 1978; Samsudin et al., 1997; Ahmad et al., 2002; Arnórsson et al., 2002; Gemici et al., 2003; Dotsika et al., 2006). The most important of these is for the production of geothermal energy (Mock, 1993; Vimmerstedt, 1998; Bahati, 2003).

\footnotetext{
* To whom all correspondence should be addressed.

푬 +27 12352 4284; fax: +27 123524270 ;

e-mail: olivij@unisa.ac.za

Received 22 June 2007; accepted in revised form 4 February 2008
}

According to DiPippo (1999) electricity first flowed from a geothermal source in the Tuscany village of Larderello in Italy more than 100 years ago. A geothermal energy plant was built there in 1914. This was destroyed during World War II. In 1958, New Zealand became the first country to operate a commercial geothermal power plant using a liquid-dominated, hotwater type reservoir at Wairakei. This was followed by the USA in 1960. By 1999, the USA had become the largest generator of geothermal electricity with an installed capacity of $2850 \mathrm{MW}$ (DiPippo, 1999, Dickson and Fanelli, 2004). By 2000, geothermally-fuelled electric power was being generated by 21 nations around the world (Huttrer, 2001). It was estimated that by 2005 , their capacity would exceed $11400 \mathrm{MW}$. Only two countries in Africa reported on geothermal power generation in 2000. These are Kenya (45 MW) and Ethiopia (8.5 MW) (Huttrer, 2001). According to Saba et al. (2004), over 60 countries around the world use geothermal energy as a source for power generation or in direct use application.

Thermal spring waters are increasingly being used for industrial processing, agriculture, aquaculture, bottled water and the extraction of rare elements (Lund, 2000; Baradács et al., 2001; Lund and Freeston, 2001; Atkinson and Davidson, 2002; Shevenell et al., 2002; Hellman and Ramsey, 2004; Petraccia et al., 2005). Moreover, with the increasing popularity of spas and the growing importance attached to the 'natural' health industry, thermal springs are again becoming centres of balneology (hydrotherapy) (Lund, 1996; Laboutka and Vylita, 1983; Bojadgieva et al., 2002; Harvey, 2007).

Thermal springs are thus natural resources that, if developed optimally, could make a considerable contribution to the local and regional economy. However, care should be exercised when making decisions regarding the appropriate use of the springs. A number of studies have found that geothermal water may con- 
tain toxic elements such as arsenic and mercury (Mandal and Suzuki, 2002; Romero et al., 2003; Churchhill and Clinkenbeard, 2005), radio-active elements (Kempster et al., 1996; Baradács et al., 2001) and pathogenic organisms such as the meningitiscausing Naeglerias fowleri (Sugita et al., 1999; Izumiyama et al., 2003; Craun et al., 2005) and Legionella pneumonia (Miyamoto et al., 1997).

South Africa is relatively richly endowed with thermal springs with the Limpopo Province having more than any of the other provinces. A number of hot springs have been developed for recreational and tourism purposes, with facilities including swimming pools, jacuzzis and spas fed by water from the spring. At some, water is bottled and sold for therapeutic purposes, and in some instances, the thermal spring is the sole source of water for the entire resort. A few thermal springs remain in private hands for exclusive use by the land owner. However, there are a few - predominantly those located in previous homelands - that remain completely undeveloped.

In view of the diversification in the number of uses of geothermal waters and development of thermal spring resources in other parts of the world, it seems likely that interest in South African thermal springs will be rekindled in the near future. The development of thermal spring resources could make a considerable contribution to the socio-economic status of people living in the poorer parts of the country, such as the Limpopo Province.

Like all natural resources, thermal springs should be managed in a sustainable manner. The availability of current scientific information on thermal springs and their properties is a prerequisite for sound decision-making regarding resource use and development. Unfortunately, most research on South African thermal springs was conducted during the 1910s and 1950s. The past 50 to 100 years have seen considerable changes in land use but it is not known whether they have had an impact on thermal springs of the region. This article presents current information on thermal springs located in the southern part of the Limpopo Province. Since the optimal use of a thermal spring is largely dependent on its physical and chemical characteristics, the article focuses on the temperatures, flow rates and the chemical composition of the thermal spring waters. A detailed overview on previous research findings is included so as to provide a benchmark for the present research.

The following section gives a short note on the geological origin of thermal springs, after which a summary of previous South African research is presented.

\section{Background}

Thermal springs are natural geological phenomena that occur on all five continents. Thermal springs are by definition 'warm'; however, there is no consensus regarding the exact temperature that distinguishes a spring from a thermal spring. Two important benchmarks are recognised, namely, that of the human body $\left(36.7^{\circ} \mathrm{C}\right)$ and mean annual local air temperature (Pentecost et al., 2003). However, in view of the fact that the climate of one region differs from that of another, what is 'warm' in one region may not be considered to be such elsewhere. For this reason, the definition of a thermal spring is often based on the mean annual air temperature of the specific site. LaMoreaux and Tanner (2001:59) define springs with a water temperature 'significantly $\left(10^{\circ} \mathrm{F}\right.$ i.e. $\left.\sim 6^{\circ} \mathrm{C}\right)$ higher' than the mean annual air temperature of the surrounding area as thermal but the lack of a specific base temperature may cause difficulties in interregional comparisons. In some countries a defining temperature of around $20^{\circ} \mathrm{C}$ is used following the climatological usage of this temperature to distinguish 'mild' from 'warm' climates (Bryan, 1919; Kent, 1949). Normal human body temperature $\left(37^{\circ} \mathrm{C}\right)$ is generally accepted as the boundary between 'warm' and 'hot'.

Thermal springs originate either from recent plutonic activity (volcanic origin) or from rainwater that percolates into the ground through permeable rocks or via conduits such as joints, faults and fracture zones in less permeable rocks (meteoric origin) (LaMoreaux and Tanner, 2001). Such water may reach considerable depths before resurfacing. It is generally accepted that, for water of meteoric origin, the temperature increases at a rate of around 2 to $3^{\circ} \mathrm{C}$ per $100 \mathrm{~m}$ (geothermal gradient) (Press and Siever, 1986). The heated fluid expands and tends to rise, creating convection currents in the groundwater. If this hot, circulating groundwater encounters a fracture zone or an impermeable barrier such as a dyke, it may rise relatively quickly and reach the surface as a thermal spring. The temperature of the thermal spring thus reflects the depth of penetration of the water and the rate at which it ascends to the surface (Grasby and Hutcheon, 2001; LaMoreaux and Tanner, 2001).

The flow rate of a thermal spring is determined by the size of the aquifer, the extent of recharge (rainfall), the aquifer storage capacity, and the transmissivity and discharge capacity of both the aquifer and the conduit through which water rises to the surface (LaMoreaux and Tanner, 2001). Most thermal springs are located at topographically low points. The difference in altitude between the recharge area and the exit point determines the hydrological head, which directly affects the flow rate.

Since minerals are generally more soluble in hot water, thermal springs are often enriched with trace elements. Certain minerals dissolve more readily than others, while some rocks are richer in soluble minerals than others. The $\mathrm{pH}$ of the solvent also affects the solubility of minerals. Hence, the specific chemical composition of spring water will depend largely on the composition of the rain water, its temperature and $\mathrm{pH}$, and the geology of the aquifer and the rocks through which the water rises to the surface.

There are numerous classifications of thermal springs. A number are based on the origin of springs, and some on physical properties such as flow rate and/or temperature. Others are classified according to geology, chemical composition or a combination of these (LaMoreaux and Tanner, 2001).

\section{Thermal springs of South Africa}

\section{Overview of previous research on South African thermal springs}

South Africa has a relatively large number of thermal springs especially for a country in which no recent volcanic activity has occurred (Kent, 1949).

The first research on Southern African thermal springs was conducted by Gumprecht in 1851 (Kent, 1949). However, the undisputed pioneers of research on thermal springs were Prof. MR Rindl during the early part of the $20^{\text {th }}$ Century and Prof. Leslie (LE) Kent, during the 1940s and 50s (Rindl, 1916; 1918; 1928; 1930; 1931; 1932; 1934; Rindl and Ing., 1937; Kent, 1952; 1946; 1948; 1949; 1969; Kent and Russell, 1950). Other research was sporadic, often centring on a single thermal spring (Rose, 1910; Du Toit, 1918, 1928; Söhnge, 1945; Gevers, 1942, 1963; Von Backström, 1962; Hoole, 2001) or confined to specific geographical regions (Temperley, 1975; Hoffmann, 1979; Marzor and Verhagen, 1983; Visser, 1989; Van Vuuren, 1990; Diamond and Harris, 2000). Both Kent (1969) and Hoffmann (1979) gave 
'updated' and comprehensive overviews of the physical and chemical composition of Southern African thermal springs. In 1981 Booyens published an informative work on the historical development of South African thermal springs, while Boekstein (1998) focused on the tourism aspects of the springs. It should be noted that the last detailed scientific studies on thermal springs in Limpopo were conducted almost 30 years ago. Since then, considerable changes in land use have taken place.

\section{Origin of South African thermal springs}

Since there is no evidence of recent volcanic activity, it is generally assumed that all thermal springs in South Africa are of a meteoric origin (Rindl, 1916; Kent, 1949; 1969; Hoffmann, 1979; Ashton and Schoeman, 1986; Visser, 1989; Diamond and Harris, 2000). Geological studies have also shown conclusively that the origin of each individual thermal spring can be attributed to the local presence of deep geological structures such as folds, fractures, faults and dykes that provide a means for the circulation to depth and the return of the heated waters to the surface.

In view of their meteoric origin, it is not surprising that most of the thermal springs originate in valleys or low-lying areas (Kent, 1952). Since sufficient rain needs to fall in the catchment areas of the springs, South African thermal springs are confined to areas with an annual rainfall in excess of $254 \mathrm{~mm}$ (10 inches) (Hoffmann, 1979).

\section{Geographical distribution}

Almost all of the thermal springs in South Africa are confined to a broad band ( $400 \mathrm{~km}$ wide) extending across more than half of the country: from Piketberg in the Western Cape through KwaZulu-Natal, the Free State and Gauteng, up to the Soutpansberg in Limpopo Province (Kent, 1952). However, the exact number of thermal springs in South Africa is not known. In 1916 Rindl described the properties of 67 medicinal springs located in South Africa, Namibia, Zimbabwe and Zambia. Only 34 of the 58 South African springs were deemed to be thermal. Nine of them are located in the Eastern Cape, eight in the Western Cape and Limpopo Province respectively, four in the Free State, three in Mpumalanga, and two in KwaZulu-Natal.

In 1949 Kent identified 74 thermal springs and 9 thermal artesian boreholes in South Africa. The latest count gives the number of thermal springs at 'over 87' (Kent, 1969; Mazor and Verhagen, 1983: 315). Many of these have been developed into holiday resorts.

Information extracted from maps by Kent (1949), Boekstein (1998) and Hoole (2001) was used to compile Fig. 1, indicating the distribution of thermal springs in the 9 provinces of the country. According to these figures the Limpopo Province is not only the most richly endowed with thermal springs (Kent, 1949), but also has the greatest number of developed thermal spring resorts.

\section{Physical and chemical characteristics}

Given the mostly warm climatic conditions prevailing through-

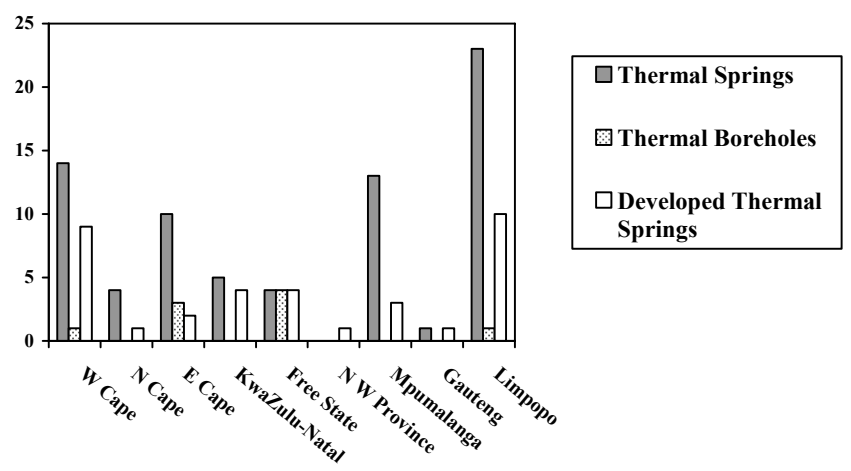

Figure 1

Provincial distribution of thermal springs and boreholes (Kent, 1949) and developed thermal springs (Boekstein, 1998; Hoole, 2001)

out South Africa, a temperature of $25^{\circ} \mathrm{C}$ is generally used to distinguish thermal from non-thermal springs. The classification used for South Africa, as proposed by Kent in 1949, is as follows: 25 to $37^{\circ} \mathrm{C}=$ warm; 38 to $50^{\circ} \mathrm{C}=$ hot or hyperthermic; $>50^{\circ} \mathrm{C}=$ scalding. The term 'tepid' is used for thermal waters with temperatures ranging between mean air temperature and $25^{\circ} \mathrm{C}$.

Using these 'threshold' temperatures, Kent (1949) classified 39 of the 74 springs as warm $\left(25\right.$ to $\left.37^{\circ} \mathrm{C}\right), 24$ as hot $(37$ to $\left.50^{\circ} \mathrm{C}\right)$ and 6 springs as scalding $\left(>50^{\circ} \mathrm{C}\right)$. He did not have sufficient information to classify the remaining five. It is generally accepted that the hottest spring in South Africa is Brandvlei $\left(64^{\circ} \mathrm{C}\right)$, near Worcester in the Western Cape. The other scalding hot springs are: Tshipise (Limpopo, $57^{\circ} \mathrm{C}$ ), Tugela Valley (KwaZulu-Natal, 52 to $53^{\circ} \mathrm{C}$ ), Warmbaths (Limpopo, $52^{\circ} \mathrm{C}$ ), Olifants Valley (Western Cape; 50 to $51^{\circ} \mathrm{C}$ ), and Badplaas (Mpumalanga, $50^{\circ} \mathrm{C}$ ). It was also found that the hottest springs generally had the highest flow rate (Kent, 1949) with Loubad (Limpopo) being a notable exception (Kent, 1946).

The concentrations of dissolved salts, nutrients and trace elements found in thermal waters are variable and reflect regional differences in climate, geology, soils and vegetation.

The chemical classification of thermal waters that is currently used in South Africa was devised by Bond in 1946. This classification distinguishes five different classes of thermal waters. These are shown in Table 1.

According to Ashton and Schoeman (1986), the total dissolved salt content of virtually all the Southern African thermal springs falls in the range of 250 to $4000 \mathrm{mg} / \ell$. They can therefore be regarded as being slightly to highly mineralised.

\section{Study area}

At least 24 of the 83 thermal springs and boreholes identified by Kent (1949) are located in the Limpopo Province (Fig. 2). They occur in two main regions or 'belts', namely in the region of the

\begin{tabular}{|c|l|l|}
\hline \multicolumn{3}{|c|}{ Classes of thermal water in South Africa according to Bond (1947) } \\
\hline Class & Water & Chemical composition \\
\hline A & Highly mineralised chloride-sulphate water & TDS $>1000 \mathrm{mg} / \ell ; \mathrm{Cl}^{-}>270 \mathrm{~g} / \mathrm{kg} ; \mathrm{SO}_{4}{ }^{=}>50 \mathrm{~g} / \mathrm{kg}$ \\
\hline B & Slightly saline chloride water & TDS $300-500 \mathrm{mg} / \ell ; \mathrm{Cl}^{-}>270 \mathrm{~g} / \mathrm{kg}^{2} \mathrm{SO}_{4}{ }^{=}<3 \mathrm{~g} / \mathrm{kg}$ \\
\hline C & Temporary hard carbonate water & TDS $<800 \mathrm{mg} / \ell ; \mathrm{pH}>7.6$ \\
\hline D & Alkaline sodium carbonate water & $\begin{array}{l}\text { TDS }<1000 \mathrm{mg} / \ell ; \mathrm{Na}_{2} \mathrm{CO}_{3} \text { or NaHCO} \\
\text { No permanent hardness }\end{array}$ \\
\hline E & 'Pure' waters & TDS $<150 \mathrm{mg} / \ell ; \mathrm{pH}<7.1$ \\
\hline
\end{tabular}




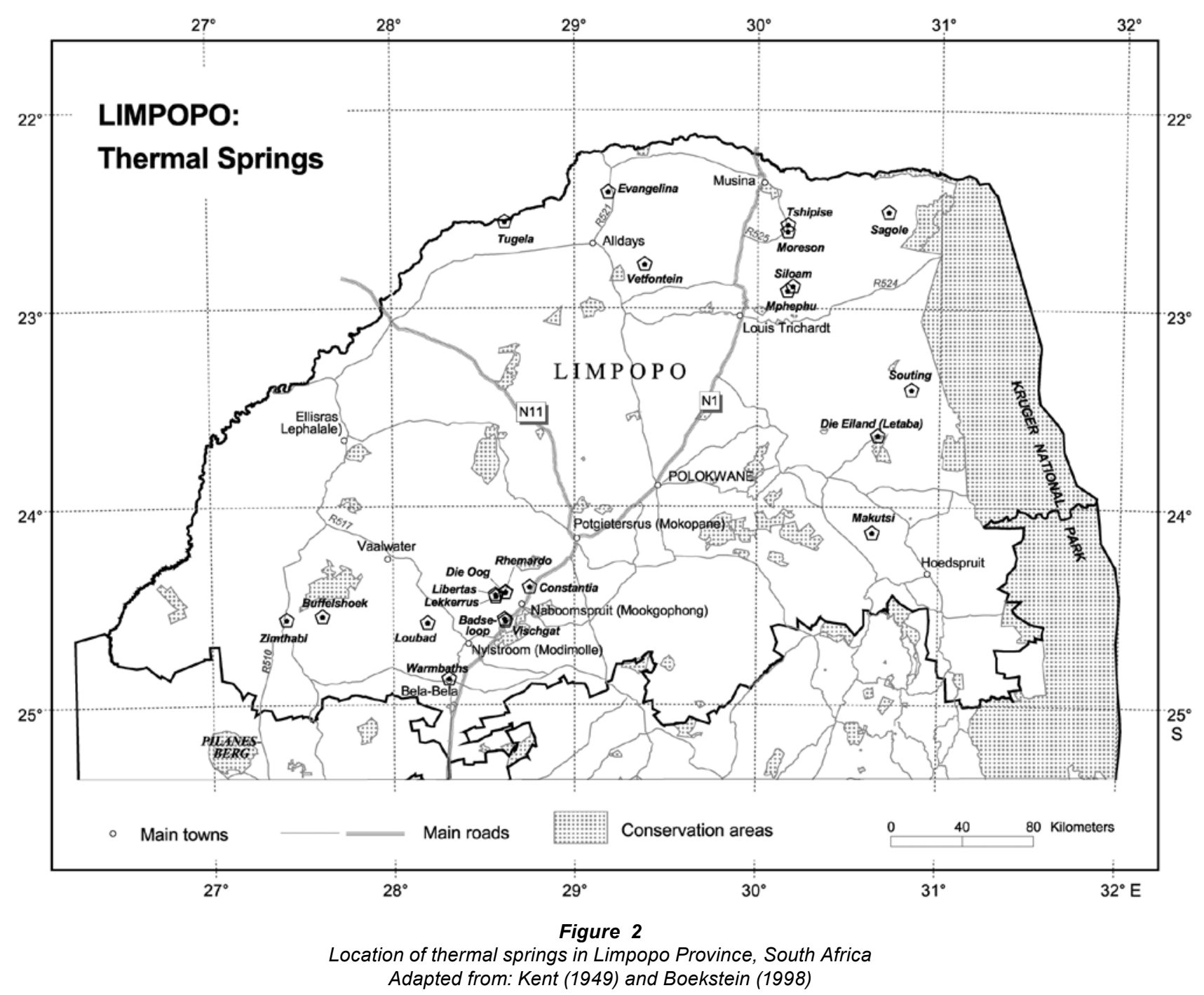

Waterberg in the south and in the vicinity of the Soutpansberg in the north. Isolated springs are found in the extreme north-west of the province and to the east of the escarpment. This paper focuses on the thermal springs in the Waterberg region of the province.

\section{Data and methodology}

A perusal of published sources and a variety of maps, including topographical maps and those produced by Kent (1949), Boekstein (1998) and Hoole (2001), indicates the existence of 13 thermal springs in the study area, namely Buffelshoek, Zimthabi, Loubad, Warmbaths, Vischgat, Die Oog, Welgevonden, Libertas, Lekkerrus, Welgevonden, Rhemardo, Badseloop and Constantia. Field trips were undertaken to the Waterberg region during 2003 to confirm their existence and to collect samples of spring water.

A number of difficulties were encountered in locating the springs, as some of those mentioned in earlier work have undergone changes in ownership and use. In some cases this has been accompanied by a change in name. The town of Warmbaths has been renamed to Bela-Bela, but the actual resort is still called Warmbaths or Warmbad, and will be referred to as such in this paper. Accurate GPS readings facilitated the identification of these springs. Rhemardo and
Welgevonden (Kent, 1949) were for instance found to be the same place. Topographical maps also indicated a hot water spring at Constantia, to the east of Die Oog. However, on visiting the resort, it was found that the spring at Constantia had in fact dried up. The reason for this is not known, although it may be due to the abstraction of underground water for other uses such as agriculture. Difficulties experienced with the identification of sampling points were further exacerbated by the number of orifices or 'eyes'. Although the majority of thermal springs have only one eye, some have numerous. Loubad, for example, has seven different eyes located within a radius of $500 \mathrm{~m}$ from each other (Kent, 1946). According to the resort managers, the 'springs' at Libertas and Lekkerrus are similar in all respects and can therefore be regarded as having the same origin. Some of the literature consulted (Temperley, 1975; Hoffmann, 1979) provides information on both, but samples were collected from Libertas only. In view of their proximity to each other $(<1 \mathrm{~km})$, the springs at Vischgat guesthouse and Badseloop youth camp could possibly be eyes of the same spring. However, visits to the sites revealed that the thermal water at the youth camp issues from a borehole and not from a spring.

During field trips undertaken during 2003, data were obtained for Vischgat, Die Oog, Welgevonden/Rhemardo, Libertas, Lekkerrus, Loubad and Warmbaths. Data for 


\begin{tabular}{|l|l|}
\hline \multicolumn{2}{|c|}{ Geological structure associated with thermal springs in Limpopo } \\
\hline Name & Geological structure \\
\hline Warmbaths (Bela-Bela) & Intersection of two post-Permian faults in Waterberg System \\
\hline Loubad & Diabase dyke in sandstones of Waterberg System (pre-Cambrian) \\
\hline Buffelshoek & Diabase dyke as barrier on artesian slope of Bushveld granite \\
\hline Vischgat & Post-Karoo fault in Bushveld granite \\
\hline Die Oog & Diabase dyke along post-Karoo fault on Rooiberg felsites \\
\hline Welgevonden/Rhemardo & Diabase dyke along post-Karoo (post-Permian) fault on Rooiberg felsites \\
\hline Lekkerrus & Diabase dyke along post-Karoo fault on Rooiberg felsites \\
\hline Libertas & Diabase dyke along post-Karoo fault on Rooiberg felsites \\
\hline $\begin{array}{l}\text { Adapted from: Bond, 1947; Kent 1946, 1949, 1952, 1969; Kent and Russell, 1950; Hoffmann 1979; } \\
\text { Ashton and Schoeman, 1986 }\end{array}$ \\
\hline
\end{tabular}

Buffelshoek were extracted from literature (Kent, 1949; Kent and Russell, 1950).

Where possible, the temperature of the water was measured at the source of the springs, using a laboratory quality glass mercury thermometer. In some cases, the source of the spring had been enclosed and was not accessible. Water samples were also collected at source and stored at low temperatures (around $4^{\circ} \mathrm{C}$ ) in $1 \ell$ sample bottles before being submitted to the Institute of Water, Climate and Soil at the Agricultural Research Council (ARC) in Pretoria for chemical analysis. No gas samples were collected. It was not possible to collect flow rate data, since pumps have been installed at the majority of developed thermal spring resorts. Past flow rate data were obtained from Kent (1949), Kent and Russell (1950) and Hoffmann (1979) and have been included for the sake of completeness.

The results are depicted by means of maps and tables. A Piper diagram (Fig. 3) has been used to illustrate the chemical composition of thermal waters. The Piper diagram is widely used in geohydrology to facilitate the interpretation of the genesis of the chemical character of groundwater in an aquifer. It consists of a tri-linear diagram on which the concentrations of the major ions are plotted as percentages, with each point representing a chemical analysis. The two base triangles reflect the sample anion and cation concentrations, respectively.

\section{Results and discussion}

\section{Structural controls}

As all South African thermal springs are of meteoric, rather than volcanic origin (Kent 1949), it follows that geology plays a vital role in the physical and chemical characteristics of the water. Three geological formations are found in the vicinity of the thermal springs in the southern part of Limpopo Province, namely the Rooiberg felsites, the Bushveld granites and the Waterberg sandstones (Kent, 1949). The geological strata are intensely faulted and fractured, and intersected by numerous diabase dykes. Although the felsites, granites and sandstones are massive rocks and are thus fundamentally impermeable, they are well fractured and faulted and this leads to particularly high infiltration rates in the sandstones.

Faulting and differential weathering may also result in considerable changes in surface geology over short distances. At Warmbaths (Bela-Bela), for example, the rock on the surface consists of basalt from the Letaba Formation (Lebombo Group, Karoo Supergroup); while at Loubad, sandstones and trachyte from the Swaershoek Formation (Nylstroom Group, Waterberg Supergroup) are exposed at the surface; and at die

\begin{tabular}{|l|l|l|}
\hline \multicolumn{3}{|c|}{ TABLE 3 } \\
\multicolumn{2}{|c|}{$\begin{array}{c}\text { Thermal characteristics of hot water springs in } \\
\text { southern Limpopo Province }\end{array}$} \\
\hline Name & $\begin{array}{l}\text { Temperature } \\
\left({ }^{\circ} \mathrm{C}\right)\end{array}$ & $\begin{array}{l}\text { Classification } \\
\text { (according to Kent } \\
\text { 1949) }\end{array}$ \\
\hline Loubad & $30^{\# *}$ & Warm \\
\hline Buffelshoek & $31^{*}$ & Warm \\
\hline Vischgat & $40^{\#}$ & Hot \\
\hline Die Oog & $40^{\# *}$ & Hot \\
\hline Welgevonden/Rhemardo & $44^{\# *}$ & Hot \\
\hline Lekkerrus & $46^{* *}$ & Hot \\
\hline Libertas & $52^{\# *}\left(38^{* *}\right)$ & Scalding \\
\hline Warmbaths & $52^{\# *}\left(60^{* *}\right)$ & Scalding \\
\hline Kent (1950) ${ }^{*} ;$ Hoffmann $(1979)^{* *} ; 2003^{\#}$ \\
\hline
\end{tabular}

Oog, massive porphyritic rhyolite from the Kwaggasnek formation (Rooiberg Group, Transvaal Supergroup) form the land surface. However, the surface geology does not necessarily reflect the true origin of the spring water or explain its particular characteristics. The origin must be sought and/or can be inferred from the chemical composition of the water, its temperature and the local geothermal gradient and knowledge of the structural geology of the area.

Information on the structural controls associated with the springs was obtained from literature and from perusal of geological maps of the area. This is summarised in Table 2 .

According to Table 2, all 8 thermal springs are associated with faulting while Loubad, Welgevonden/Rhemardo, Die Oog, Lekkerrus and Libertas are associated with the presence of diabase dykes.

\section{Temperature}

Several holiday resorts in Limpopo claim to be 'mineral hot springs'. However, only the eight mentioned previously are truly thermal springs. Other resorts use other sources of water and alternative sources of heating for their swimming pools and jacuzzis.

The temperatures measured at the source of the true thermal springs are listed in Table 3.

Two of the springs in the southern part of Limpopo are classified as scalding, four as hot, and two as warm. From a perusal of Table 3 it appears that there is no spatial correlation between springs with similar thermal characteristics. While the temperature at adjacent thermal springs may be similar, for instance those of Welgevonden/Rhemardo $\left(44^{\circ} \mathrm{C}\right)$ and Die $\operatorname{Oog}\left(40^{\circ} \mathrm{C}\right)$, 


\begin{tabular}{|c|c|c|}
\hline \multicolumn{3}{|c|}{$\begin{array}{c}\text { TABLE 4 } \\
\text { Flow rates of thermal springs according to Kent } \\
(1949) \text { and Hoffmann (1979) }\end{array}$} \\
\hline Name & $\begin{array}{c}\text { Flow rate in } \\
\mathrm{m}^{3} / \mathrm{d}\left[\mathrm{m}^{3} / \mathrm{h}\right] \\
\text { (Kent, 1949) }\end{array}$ & $\begin{array}{c}\text { Flow rate }\left(\mathrm{m}^{3} / \mathrm{h}\right) \\
\text { (Hoffmann, } \\
\text { 1979) }\end{array}$ \\
\hline Warmbaths & $30.25[1.26]$ & 8 \\
\hline Loubad & $78.29[3.26]$ & - \\
\hline Buffelshoek & $3.21[0.13]$ & - \\
\hline Vischgat & $3.79[0.16]$ & - \\
\hline Die Oog & $6.04[0.25]$ & 136 \\
\hline Welgevonden/Rhemardo & $2.38[0.10]$ & 25 \\
\hline Lekkerrus & - & 68 \\
\hline Libertas & - & 36 \\
\hline
\end{tabular}

others may show a marked difference. Warmbaths, for instance, has a temperature of $52^{\circ} \mathrm{C}$, whereas at Loubad, its nearest neighbour $\left(43 \mathrm{~km}\right.$ apart), the temperature is a mere $30^{\circ} \mathrm{C}$.

Comparison between current temperatures and those recorded by Kent (1949) shows no significant change. It thus appears that in terms of thermal characteristics, thermal springs have remained stable over the last 50 to 60 years.

\section{Flow rate}

As noted earlier, it was not possible to measure flow rates, since the springs at the resorts have been fitted with pumps. Data obtained from Kent (1949) and Hoffmann (1979) are given in Table 4.

The flow rates measured at the thermal springs by Kent (1949) vary considerably, from $57 \mathrm{~m}^{3} / \mathrm{d}$ at Welgevonden/Rhemardo to over $1800 \mathrm{~m}^{3} / \mathrm{d}$ at Loubad and from $136 \mathrm{~m}^{3} / \mathrm{h}$ at Die Oog to $8 \mathrm{~m}^{3} / \mathrm{h}$ at Warmbaths. Unfortunately the flow rate values reported by Kent in 1949 and Hoffmann in 1979 do not correspond (Table 4). It should be noted that Kent (1949) gives flow rates in $\mathrm{m}^{3} / \mathrm{d}$, while Hoffmann (1979) reports them in $\mathrm{m}^{3} / \mathrm{h}$. To facilitate comparison, Kent's data have been converted to $\mathrm{m}^{3} / \mathrm{h}$ and are given in square brackets.

It is evident that either some of the data are incorrect or the flow rate has changed radically during the period 1949 and 1979. A decrease in flow rates could have been caused by the extraction of large volumes of water for activities such as agriculture, but the data indicate an unexpected substantial increase in flow rates at some springs. If flow rates have indeed changed over time, the assertion by Kent (1949) and Diamond and Harris (2000: 469), that 'the constancy of discharge temperature and volume is a generally known fact', is not correct.

Previous studies by Kent (1949) and Diamond and Harris (2000) indicated that the hottest springs in South Africa usually also have the highest flow rates, with Loubad being the notable exception (Kent, 1969). A comparison of temperatures and flow rates recorded by Kent (1949), as shown in Tables 3 and 4, gives a Pearson's Linear Correlation Coefficient of $r=0.30$. Although $r$ increases to +0.77 if Loubad is excluded, it is still not statistically significant at even the 5\% level (Student's t-test; $n=6$ ). There is thus no linear relationship between flow rate and temperature of thermal springs located in the study area.

\section{Chemical characteristics}

\section{Major elements and ions}

Thermal springs are usually mineralised to a greater or lesser extent, depending on the characteristics of the geological formations associated with the circulating groundwater. The results of the chemical analyses (by ARC, Pretoria) of water samples collected from Vischgat, Die Oog, Welgevonden/Rhemardo, Lekkerrus, Libertas and Loubad are given in Table 5. Information for Warmbaths and Buffelshoek, as extracted from Temperley (1975) and Hoffmann (1979), are included to facilitate comparisons. Standards provided by the South African Bureau of Standards (SABS) 1999 for Class 1 potable water are given to facilitate evaluation of water quality.

Water samples from Vischgat, Die Oog, Welgevonden/ Rhemardo, Lekkerrus and Libertas share a number of chemical characteristics. They all have $\mathrm{pH} \sim 7$; are neutral (neither corrosive nor depositional: $\mathrm{pH}_{\mathrm{s}}-\mathrm{pH}=-1$ to +1 ); have conductivity values of 25 to $52 \mathrm{mS} / \mathrm{m}$; and (SAR) values of more than 1 . The latter indicates that they are not suitable for irrigation. According to Bond's classification (1947) all springs, except Warmbaths and Buffelshoek, can be classified as 'pure' waters, the latter two being alkaline sodium carbonate waters. However, only Loubad's water is suitable for human consumption. The other springs have fluoride levels exceeding the $1 \mathrm{mg} / \ell$ recommended by the South African Guidelines for Domestic Water Quality (DWAF, 1996).

In the majority of cases, barring Loubad and Libertas, the dominant cation is sodium with calcium being subdominant, followed by potassium and magnesium. The ratio of calcium to magnesium is consistently high, ranging from $6: 1$ at Libertas to 12: 1 at Vischgat. All the thermal waters are rich in bicarbonates and (with the exception of Vischgat), poor in sulphates. The chloride levels of the different springs vary. Waters from Warmbaths and Buffelshoek have higher concentrations of chlorine, but it is virtually absent from Loubad and Vischgat. Water from Vischgat contains relatively more sulphates than do the other spring waters. Carbonates, phosphates and nitrates are absent or present in very low concentrations. At Loubad, the sodium concentration of water is significantly lower than at the other springs, while the concentration of calcium is relatively higher. The dominant anion is also bicarbonate, but the water contains very little chloride and sulphate.

A Piper diagram (Fig. 3) was used to illustrate the chemical character of the thermal spring waters and to identify the degree of correspondence between the source areas of the springs. The geohydrochemical processes to which thermal spring waters were subjected can also be inferred from these diagrams. The explanation of the Piper diagram is based on that of Johnston (1975) as given in Lloyd and Heathcote (1985).

The top diamond-shaped field on the Piper diagram (Fig. 3) provides irrefutable evidence that waters from Die Oog and Rhemardo have identical hydrochemical characteristics and therefore share a common source area. Waters issuing from the thermal springs at Buffelshoek and Warmbaths also share a common origin, the slight differences probably reflecting different depths of origin. Separate aquifers, distinct from the others, feed the springs at Vischgat and Loubad. The cation composition at Loubad differentiates it from the other thermal springs, while at Vischgat, the anion content is the distinguishing feature. It is interesting to note that Loubad and Libertas share many characteristics in terms of anion composition (lower RHS triangle on Fig. 3) whereas Vischgat and Die Oog are similar in terms of cation composition.

All thermal springs (except Vischgat) exhibit dynamic and coordinated hydrochemical regimes. At Vischgat, the dominant 
TABLE 5

Chemical composition of thermal springs in Limpopo

\begin{tabular}{|c|c|c|c|c|c|c|c|c|}
\hline & SABS 1999 & Warmbad* & Loubad & Buffelshoek* & Vischgat & Die Oog & Rhemardo & Libertas \\
\hline $\mathrm{pH}$ & $6-9$ & 8.3 & 6.81 & \multirow{5}{*}{$\begin{array}{c}\text { Not } \\
\text { available }\end{array}$} & 7.07 & 7.27 & 7.33 & 6.98 \\
\hline $\mathrm{pH}_{\mathrm{s}}$ & & & 7.79 & & 7.82 & 8.01 & 7.96 & 8.00 \\
\hline SAR & & & 0.34 & & 2.39 & 1.72 & 1.62 & 1.13 \\
\hline TDS & $<450$ & 340 & 134.18 & & 302.85 & 175.48 & 179.90 & 137.90 \\
\hline $\begin{array}{l}\text { Conduct. } \\
(\mathrm{mS} / \mathrm{m})\end{array}$ & $<150$ & 69 & 25.00 & & 52.00 & 32.00 & 34.00 & 25.00 \\
\hline \multicolumn{9}{|c|}{ CATIONS (mg/e) } \\
\hline Sodium & $<200$ & 132.5 & 7.87 & \begin{tabular}{|l|}
151.6 \\
\end{tabular} & 55.95 & 34.21 & 32.72 & 21.98 \\
\hline Potassium & $<50$ & 2.9 & 2.90 & 5.7 & 6.13 & 3.62 & 3.58 & 3.57 \\
\hline Calcium & ns & 13.0 & 30.92 & 27.1 & 36.13 & 24.80 & 25.57 & 23.02 \\
\hline Magnesium & ns & 1.8 & 6.44 & 4.7 & 3.30 & 3.14 & 3.28 & 3.46 \\
\hline Boron & $<1.5$ & & 0.04 & & 0.06 & 0.05 & 0.05 & 0.05 \\
\hline \multicolumn{9}{|c|}{ ANIONS (mg/e) } \\
\hline Fluoride & $1.5\left(1^{\#}\right)$ & 11.0 & 0.95 & 6.6 & 6.54 & 5.66 & 5.39 & 5.95 \\
\hline Nitrite & Ns & - & 0.00 & - & 0.12 & 0.00 & 0.00 & $<0.1$ \\
\hline Nitrate & $\mathrm{Ns}$ & 0 & 0.59 & 0 & 0.68 & 0.60 & 0.88 & 0.41 \\
\hline Chloride & $<200$ & 85.2 & 2.21 & 138.5 & 31.70 & 28.31 & 28.64 & 7.24 \\
\hline Sulphate & $<400$ & 12.1 & 2.16 & 35.1 & 92.82 & 12.96 & 13.68 & 5.86 \\
\hline Phosphate & ns & $<0.2$ & 0.00 & - & 0.00 & 0.00 & 0.00 & $<0.2$ \\
\hline Carbonate & ns & - & 0.00 & - & 0.00 & 0.00 & 0.00 & 0.00 \\
\hline Bicarb & ns & 102.0 & 161.65 & 213.5 & 140.30 & 125.05 & 134.20 & 134.2 \\
\hline $\begin{array}{l}\text { Classific. } \\
\text { (Bond 1946) }\end{array}$ & & $\mathrm{D}$ & $E$ & $\mathrm{D}$ & $\mathrm{E}$ & $\mathrm{E}$ & $\mathrm{E}$ & $\mathrm{E}$ \\
\hline
\end{tabular}

Source: *Kent, 1949; Temperley, 1975 (as reported in Hoffmann, 1979 p8) ; **Hoffmann, 1979 p15

\#DWAF, 1996; ns: not stipulated

process is dissolution and mixing. Relatively little ion exchange has occurred at Libertas and Loubad, whereas Warmbaths and Buffelshoek have undergone considerably more concentration and precipitation processes.

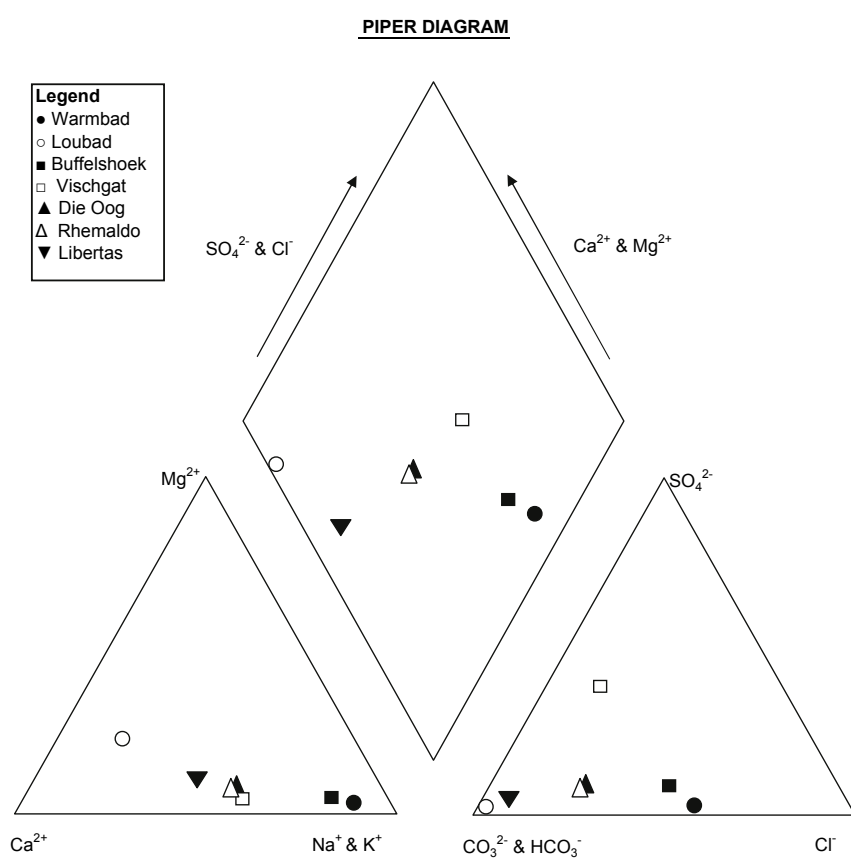

Figure 3

Piper diagram showing the chemical characteristics of southern Limpopo Province thermal springs waters

\section{Influence of geology on chemical characteristics}

Although the chemical characteristics of thermal waters are largely determined by the rocks through which the hot water circulates, it is not always easy to match the composition of thermal spring waters with 'their vagaries in geological formations' (Kent, 1949). It is not necessarily the surface formations that affect the mineral content of the water, but those formations occurring at the depth at which the groundwater circulates.

The three most important geological formations found at depths in the vicinity of the thermal springs in the southern part of Limpopo Province are the Rooiberg Group of felsites, the Bushveld granites and the Waterberg Supergroup sandstones. The Rooiberg Group is Pre-Cambrian in age and comprises felsitic lavas and sediments (Kent, 1949). The characteristic dissolvable constituents are $\mathrm{NaHCO}_{3}$ and $\mathrm{Ca}\left(\mathrm{HCO}_{3}\right)_{2}$, with subordinate $\mathrm{NaCl}$. The Rooiberg Group markers have excessive amounts of $\mathrm{Ca}^{++}$over $\mathrm{Mg}^{++}$(Kent, 1949).

Typically, waters issuing from Bushveld granites have a relatively higher sodium chloride and sodium carbonate content. The main point of difference is the $\mathrm{Ca}^{++}: \mathrm{Mg}^{++}$ratio, which is about $6.5: 1$ for the thermal waters and 2:1 for the cold borehole waters (Kent, 1949).

The Waterberg Supergroup is composed of a thick succession of sandstones rich in iron and low in feldspar (Bond, 1947; Kent, 1949). Waters issuing from this system are characteristically low in minerals, the main constituent being $\mathrm{Ca}\left(\mathrm{HCO}_{3}\right)_{2}$; low concentrations of $\mathrm{Cl}^{-}$; and virtually no $\mathrm{SO}_{4}=$.

The hot waters from the majority of the springs do not reflect surface geology. Thermal spring water at Die Oog, Rhemardo, Lekkerrus and Libertas rise from faults in the felsites (Table 2) and reflect the characteristics of the Rooiberg felsites, whereas the thermal springs at Warmbaths (Bela-Bela) and Vischgat 
clearly rise from the Bushveld granite. The thermal water at Loubad obtains its characteristics from the underlying Waterberg sandstones.

The composition of the water at Buffelshoek is also unlike other springs in Waterberg sandstones, but is virtually identical to that of Warmbaths. Using a geothermal gradient of $67 \mathrm{~m}$ per $1^{\circ} \mathrm{C}$, it was estimated that meteoric water would descend to a depth of about $915 \mathrm{~m}$ where the rock temperature would be about $31^{\circ} \mathrm{C}$ (Kent and Russell, 1950). At the eye of the spring the water temperature is $30.5^{\circ} \mathrm{C}$. Bushveld granite is present at this depth. The water probably percolates into Bushveld (red) granite until the barrier formed by the dyke is reached. Another peculiarity of Buffelshoek is the relatively high $\mathrm{SO}_{4}{ }^{=}$, which suggests the presence of pyrite in some of the rocks leached by the water (Kent, 1949: 255; Kent and Russell, 1950).

The chemical composition of Loubad is typically that of sandstone waters. It represents deep, artesian water from the basal layers of the system (the estimated depth of origin is around $1097 \mathrm{~m}$ ) (Kent, 1946: 164). The preponderant cations present, namely $\mathrm{Ca}^{++}, \mathrm{Na}^{+}$and $\mathrm{K}^{+}$, are probably derived from feldspars, while diabase intrusions possibly supply most of the $\mathrm{Mg}^{++}$. The dominant anion, $\mathrm{HCO}_{3}^{-}$, has its source in atmospheric $\mathrm{CO}_{2}$, while the $\mathrm{Cl}^{-}$is subordinate to $\mathrm{Na}^{+}$and may well be of cyclic origin. The water contains only a small amount of sulphate $-\mathrm{a}$ characteristic of waters that percolate through sandstone. The intake is characterised by fractures and shatter belts associated with the strike faults near the northern contact between the Waterberg sandstones and the Rooiberg felsites. The fissures at or near the crest of a sharp anticline in this area facilitate rapid vertical water movement, resulting in a minimal loss of heat during ascent.

It is evident that proximity of springs to each other does not necessarily indicate identical physical and chemical characteristics. Loubad and Warmbaths are only $43 \mathrm{~km}$ apart, yet their physical and chemical characteristics differ, whereas those of Buffelshoek and Warmbaths (50 km apart) are almost identical.

\section{Trace elements}

Water samples from the 5 thermal springs visited were analysed for 29 trace elements by the Institute of Water, Climate and Soil (ARC, Pretoria).

Target ranges for domestic water quality for some of the trace elements are given by the DWAF (1996) and the SABS (1999) Standards for Class 1 potable water. These are shown in the second column of Table 6 .

According to DWAF (1996) standards, thermal water from Libertas contains an unacceptably high value of mercury, although it falls within the 'acceptable' range in the 1999 SABS Guidelines. It is immaterial whether this originates from the geological formations, or from other sources; the fact remains

\begin{tabular}{|c|c|c|c|c|c|c|}
\hline \multicolumn{7}{|c|}{$\begin{array}{c}\text { TABLE } 6 \\
\text { Concentration of trace elements in southern Limpopo thermal }\end{array}$} \\
\hline \multirow[t]{2}{*}{ Element } & \multirow{2}{*}{$\begin{array}{c}\text { DWAF } 1996 \text { * } \\
\text { SABS } 1999^{* *} \\
\text { Standards } \\
(\mu \mathrm{g} / \ell)\end{array}$} & Vischgat & Die Oog & $\begin{array}{l}\text { Welgevonden/ } \\
\text { Rhemardo }\end{array}$ & Libertas & Loubad \\
\hline & & $\mu \mathrm{g} / \ell$ & $(\mu g / \ell)$ & $(\mu \mathrm{g} / \ell)$ & $(\mu \mathrm{g} / \ell)$ & $(\mu g / \ell)$ \\
\hline Molybdenum & ns & 9.67 & 11.63 & 11.07 & 12.49 & 6.30 \\
\hline Beryllium & $\mathrm{ns}$ & 0.60 & 0.63 & 0.68 & 1.07 & 0.44 \\
\hline Boron & 1500 & 47.63 & 49.38 & 47.96 & 43.78 & 33.07 \\
\hline Titanium & $\mathrm{ns}$ & 228.59 & 134.50 & 144.68 & 141.64 & 178.96 \\
\hline Vanadium & $100 *$ & 3.78 & 4.18 & 4.30 & 3.17 & 3.71 \\
\hline Chromium & $50 * 100 * *$ & 2.84 & 3.31 & 3.56 & 3.39 & 5.52 \\
\hline Manganese & $50 * 100 * *$ & 9.63 & 3.13 & 3.52 & 14.22 & 20.14 \\
\hline Cobalt & $150 * *$ & 2.13 & 1.13 & 1.56 & 2.15 & 3.50 \\
\hline Nickel & $1000 * *$ & 8.80 & 4.43 & 7.07 & 10.18 & 17.33 \\
\hline Copper & $1000 * 5000 * *$ & 6.07 & 1.14 & 4.97 & 5.77 & 5.54 \\
\hline Zinc & 3000* & 37.54 & 9.93 & 19.53 & 14.63 & 8.65 \\
\hline Arsenic & $10 *$ & 1.35 & 3.25 & 4.48 & 6.63 & 4.23 \\
\hline Bromine & ns & 39.64 & 60.93 & 31.36 & 0.00 & 20.73 \\
\hline Lithium & $\mathrm{ns}$ & 79.54 & 45.42 & 47.14 & 37.21 & 16.43 \\
\hline Strontium & ns & 227.27 & 125.11 & 127.36 & 202.39 & 104.34 \\
\hline Uranium & $70 * * *$ & 0.00 & 1.37 & 4.12 & 2.98 & 1.28 \\
\hline Cadmium & $5 *$ & 1.79 & 0.47 & 1.20 & 0.034 & 0.93 \\
\hline Antimony & ns & 1.03 & 0.00 & 2.49 & 0.05 & 0.00 \\
\hline Tellurium & $\mathrm{ns}$ & 0.00 & 3.46 & 0.00 & 2.11 & 4.92 \\
\hline Iodine & $\mathrm{ns}$ & 15.90 & 6.96 & 7.75 & 20.08 & 0.00 \\
\hline Barium & ns & 9.47 & 13.26 & 13.27 & 29.00 & 42.26 \\
\hline Lanthanum & $\mathrm{ns}$ & 0.00 & 0.00 & 0.00 & 0.00 & 0.00 \\
\hline Tungsten & $\mathrm{ns}$ & 1.10 & 0.00 & 3.21 & 0.00 & 0.00 \\
\hline Platinum & ns & 0.00 & 0.00 & 0.00 & 0.00 & 0.00 \\
\hline Mercury & $1 * \quad 2 * *$ & 0.00 & 0.00 & 0.00 & 1.77 & 0.00 \\
\hline Thallium & ns & 0.77 & 0.64 & 0.66 & 0.39 & 0.37 \\
\hline Lead & $10 * 50 * *$ & 3.73 & 5.69 & 6.96 & 5.70 & 5.64 \\
\hline Bismuth & ns & 3.80 & 3.85 & 3.70 & 3.60 & 3.62 \\
\hline Selenium & $20 *$ & 0.00 & 0.00 & 0.00 & 0.00 & 1.66 \\
\hline
\end{tabular}


that the long-term ingestion of water from this source may be hazardous to human health.

It appears that all springs, except Libertas, conform to general health standards with regard to trace elements. It is interesting to note that most of the springs contain high levels of strontium and titanium. In comparison to other thermal spring waters, Libertas and Loubad have relatively higher concentrations of manganese and barium, Vischgat has relatively more lithium, while the water at Libertas and Vischgat are relatively rich in iodine. Water from Libertas has low cadmium levels and does not contain any bromine. Since the concentrations of these elements are not stipulated in either DWAF (1996) or SABS (1999), it is assumed that they are not detrimental to health.

\section{Temporal analysis}

It was mentioned previously that a number of factors can influence the chemical composition of thermal waters. These include, inter alia, the amount of rainfall and its composition, the $\mathrm{pH}$ and temperature of the water, and the geochemistry of the rocks through which the water passes before emerging at the surface as a spring. It is also possible that activities on the surface of the earth could affect the water quality. Numerous studies have shown that agricultural practices involving the application of large amounts of fertilisers and pesticides affect groundwater quality. Other activities such as mining, industry and the location of pit toilets in rural areas may also reduce groundwater quality (Usher et al., 2004). The southern part of the Limpopo Province has experienced major changes in land use over the last 50 years. It is not known whether this has had an influence on the quality of groundwater and the thermal spring water. Fortunately, relevant information on thermal spring chemistry exists for the 1940s (Kent, 1949) and the 1970s (Hoffmann, 1979). Comparison of the current data with these will indicate temporal changes in the chemical composition of thermal spring waters. Table 7 shows the concentration of major ions in thermal waters for the three periods spanning a total of 60 years. Very little information is available on trace element concentrations with regard to the earlier research.

Contrary to expectations, Table 7 indicates that the total dissolved solids (TDS) values at 3 thermal springs have decreased, indicating an improvement in water quality. However, the concentrations of the major ions have remained remarkably consistent over the last 50 to 60 years. It is assumed that the trend would be the same at the other springs in the study region. Surprisingly, the strontium level at all 3 springs has increased, especially at Libertas and Loubad, while the zinc concentrations have shown a marked decrease. It should be kept in mind that there have been considerable advancements in the quality and accuracy of the equipment used for chemical analysis. This could explain the minor differences in the concentrations of elements.

Major land-use changes have occurred over the past 50 to 60 years, yet very few changes were detected in the physical and chemical characteristics of the thermal spring water. There may be several explanations for this: The catchment area could still be underdeveloped, while other parts of the region could have experienced changes in land use; or the depth to which the water gravitates exceeds that of the 'zone of contamination'; or the time it takes for the water to emerge is too long to show the impact of a relatively recent event. In the latter event, a change in water quality may only become evident at a later stage.

\section{Conclusion}

This article expands and enhances the present knowledge of the physical and chemical characteristics of thermal springs in the Waterberg region of the Limpopo Province of South Africa. It gives an overview of the physical and chemical characteristics of thermal springs and provides current information on the temperature and chemical composition of 8 thermal springs in this area. This permits comparison with earlier findings so as to identify temporal variations in water quality over the last 50 to 60 years. The Limpopo Province has more thermal springs and more developed thermal spring resorts than any of the other provinces in South Africa. The springs are all of meteoric origin and range from warm to scalding in temperature. The mineral composition of the thermal waters reflects the geological formations that occur at the depth of origin of the thermal spring water, rather than the surface formations. This indicates that the spatial distribution of thermal springs does not dictate the physical and chemical characteristics of the springs and that two or

\begin{tabular}{|c|c|c|c|c|c|c|c|c|}
\hline Temporal a & ysis o & mical & acteri & $\begin{array}{l}\text { ABLE } \\
\text {; of the }\end{array}$ & sprin & Libe & Die 0 & Lou \\
\hline Conc $(\mathrm{mg} / \mathrm{l})$ & & Libertas & & & Die Oog & & & \\
\hline & 1949* & $1979^{* *}$ & 2003 & 1939* & 1979 ** & 2003 & $1941^{*}$ & 2003 \\
\hline TDS & 311 & 200 & 138 & 257 & 259 & 175 & n.a. & 134 \\
\hline & & & & Cations & & & & \\
\hline $\mathrm{Na}^{+}$ & 21 & 22 & 22 & 46 & 41 & 34 & 8 & 8 \\
\hline $\mathrm{K}^{+}$ & 2 & 4 & 4 & 0.4 & 4 & 4 & 3 & 3 \\
\hline $\mathrm{Mg}^{++}$ & 1 & 3 & 3 & 1 & 2 & 3 & 6 & 6 \\
\hline $\mathrm{Ca}^{++}$ & 26 & 23 & 23 & 19 & 33 & 25 & 26 & 31 \\
\hline & & & & Anions & & & & \\
\hline $\mathrm{Cl}^{-}$ & 7 & 10 & 7 & 25 & 25 & 28 & 4 & 2 \\
\hline $\mathrm{SO}_{4}=$ & 12 & 5 & 6 & 8 & 10 & 13 & $\operatorname{tr}$ & 2 \\
\hline $\mathrm{HCO}_{3}^{-}$ & 110 & 111 & 63 & 110 & 154 & 102 & 122 & 161 \\
\hline $\mathrm{F}^{-}$ & 3.5 & 6 & 6 & 6 & 6 & 6 & 0.5 & 1 \\
\hline & & & & ce elem & & & & \\
\hline $\mathrm{Sr}$ & n.a. & 72 & 202 & n.a. & 115 & 125 & 7 & 104 \\
\hline $\mathrm{Zn}$ & n.a. & 28 & 15 & n.a. & 165 & 10 & n.a. & n.a. \\
\hline
\end{tabular}


more springs located in close proximity to each other may differ markedly from one another with respect to their temperatures, flow rates or chemical composition and may not share the same development potential.

The differences between $\mathrm{pH}_{\mathrm{s}}$ and $\mathrm{pH}$ values of thermal spring waters are small (less than \pm 1 ) at all springs that were studied. This means that they are neither corrosive nor depositional in nature. However, SAR values of $>1$ counter-indicate their use for irrigation. Contrary to earlier findings (Kent 1952), waters from the thermal springs in the study area cannot generally be regarded as 'pure'. Unacceptably high levels of fluoride are present in water from all the thermal springs except Loubad. The waters from the majority of thermal springs in the southern part of Limpopo are thus not fit for human consumption. The quality of water from Libertas is especially suspect in view of the relatively high mercury content.

A temporal analysis of the physical characteristics of thermal springs indicates that the temperature of the water at source has remained constant over the past 50 years. The concentrations of the major ions and trace elements of spring waters have also shown little change over time. It is not known whether this is merely a reflection of the slow rate of groundwater circulation in the deep crustal rocks or whether changes in land use are confined to near-surface rocks, not affecting formations at depth. If the former applies, the water quality of the springs may change at a later stage. It is therefore important to determine the residence time of waters that emerge as thermal springs. Furthermore, in view of possible impacts on springs, great care should be taken in the type of land use practised in thermal spring catchment areas. It is clear that the present use of untreated thermal spring water for domestic purposes and as bottled drinking water is undesirable. In addition, the use of thermal spring water for recreational purposes such as swimming should be closely monitored.

It is recommended that relevant authorities, planners and developers should be alerted to the potential health hazards related to the long-term consumption of untreated thermal spring water in the area. A regular sampling and analysis programme of spring water should be initiated and the local population informed about risks, mitigation measures and treatment options. It is strongly recommended that alternative uses for thermal springs be identified and their economic potential and social and environmental impacts determined. Only then can judicious decisions be made about the optimal development for the respective thermal springs.

\section{Acknowledgements}

This research formed part of a NRF-funded project: focus area Sustainable Livelihoods: GUN: 2054058. We gratefully acknowledge their financial assistance without which the research would not have been possible. We also wish to thank Leanne Brown (UNISA library) and Ernest Tshibalo for assistance in obtaining the necessary references, Ingrid Booysen and Lynn Meyer for drafting the maps and figures, Liesl Frick for critically reading the document and Zandra Bezuidenhout for editing it. A special word of thanks to the members of the Department of Geography and the Department of Environmental Sciences, UNISA, for their assistance on field trips and to Dr S Zietsman for collecting data from Loubad.

\section{References}

LATIF Z (2002) Assessment of reservoir temperatures of thermal springs of the northern areas of Pakistan by chemical and isotope geothermometry. Geotherm. 31 (5) 613-631.

ARNÓRSSON S, GUNNARSSON I, STEFÁNSSON A, ANDRÈSDÓTTIR A and SVEINBJORNSDÓTTIR AE (2002) Major element chemistry of surface- and ground waters in basaltic terrain, N-Iceland. I. Primary mineral saturation. Geochim. Cosmochim. Acta 66 (23) 4015-4046.

ATKINSON TC and DAVIDSON (2002) Is the water still hot? Sustainability and the thermal springs at Bath, England. Geol. Soc., London, Special Publications 193 15-40.

ASHTON PJ and SCHOEMAN FR (1986) Southern African thermal springs. The Naturalist 30 (1) 32-34.

BAHATI G (2003) Geothermal energy in Uganda, country update. Proc. Int. Geotherm. Conf., Sept 2003, Reykjavik, Iceland. 48-53.

BARADÁCS E, HUNYADI I, DEZS Z, CSIGE I and SZERBIN P (2001) ${ }^{226} \mathrm{Ra}$ in geothermal and bottled mineral waters of Hungry. Radiat. Meas. 34 (1-6) 385-390.

BOEKSTEIN M (1998) Hot Springs Holidays: Visitors' Guide to Hot Springs and Mineral Spa Resorts in Southern Africa. Mark Boekstein and Logo Print, Cape Town.

BOJADGIEVA K, DIPCHIKOVA S, BENDEREV A and KOSEVA J (2002) Thermal Waters and Balneolody in Bulgaria. GHC Bulletin, March, 18-25.

BOND GW (1947) 'n Geochemiese opname van die grondwatervoorrade van die Unie van Suid-Afrika. Memoirs Geol. Surv. S. Afr. 41 90-94.

BOOYENS B (1981) Bronwaters van Genesing - Die Tradisionele Warmbronwaterkultuur in ons Volksgeneeskunde. Tafelberg, Kaapstad.

BRYAN K (1919) Classification of springs. J. Geol. 27 552-561.

CHRISTOPHER H and ARMSTEAD H (1978) Geothermal Energy: Its Past, Present and Future Contributions to the Energy Needs of Man. E. \& F.N Spon, London, UK.

CHURCHILL RK and CLINKERBEARD JP (2005) Perspectives on mercury contributions to watersheds from historic mercury mines and non-mine mercury sources: examples from the sulphur creek mining district. Cordilleran Section - $101^{\text {st }}$ Annual Meeting, Piedmont, Italy, 29 April - 1 May 2005.

CRAUN GF, CALDERON RL and CRAUN ME (2005) Outbreaks associated with recreational water in the United States. Int. J. Environ. Health Res. 15 (4) 243-262.

DEPARTMENT OF WATER AFFAIRS AND FORESTRY (1996) South African Water Quality Guidelines. Domestic Water Quality. http://www.dwaf.gov.za (Accessed 13 December 2006)

DIAMOND RE and HARRIS C (2000) Oxygen and hydrogen isotope geochemistry of thermal springs of the Western Cape, South Africa: Recharge at high altitude? J. Afr. Earth Sci. 31 (3/4) 467-481.

DICKSON M H and FANELLI M (2004) What is geothermal energy? International geothermal Association (IGA) http://iga.igg.cnr.it/geo/ geoenergy.php (Accessed 13 September 2006).

DIPIPPO R (1999) Small Geothermal Plants: Design, performance, and economics. GHC Bulletin, June, 1-8.

DOTSIKA E, LEONTIADIS I, POUTOUKIS D CIONI R and RACO B (2006) Fluid geochemistry of the Chios geothermal area, Chios Island, Greece. J. Volcanol. Geotherm. Res. 154 (3-4) 237-250.

DU TOIT AL (1918) The geology of the crystalline limestone deposits near Port Shepstone and Hermansburg, Natal. Memoir Geol. Surv. S. Afr. 11 115-116.

DU TOIT AL (1928) The underground water resources of the Uitenhage region. Explanations Cape Sheet no. 9 (Port Elizabeth), Geol. Surv. S. Afr. 40-41.

EDMUNDS WM (2004) Bath thermal waters: 400 years in the history of geochemistry and hydrogeology. Geol. Soc., London, Special Publication 225 193-199.

ENCARTA ENCYCLOPEDIA (1997). Microsoft Publication.

FERREIRA SLA (1992) 'n Ruimtelike Analise van die Distriksekonomie van Warmbad (Transvaal). Unpublished D. Litt. Thesis, University of South Africa, South Africa.

GEMICI Ü, TARCAN G, ÇOLAK M and HELVACI (2003) Hydrogeochemical and hydrogeological investigations of thermal waters in the Emet area (Kütahya, Turkey). Appl. Geochem. 19 (1) 105-117. 
GEVERS TW (1942) The hot springs in the Tugela River near Kranskop, Natal. Trans. Geol. Soc. S. Afr. 45 65-74.

GEVERS TW (1963) Thermal Springs at Lilani, Natal, and their geological settings. Trans. Geol. Soc. S. Afr. 65129 -155.

GRASBY E and HUTCHEON I (2001) Controls on the distribution of thermal springs in the southern Canadian Cordillera. Can. J. Earth Sci. 38 (3) 427-440.

HARING M, RACHEL R, PENG X, GARRETT RA and PRANGISHVILI D (2005) Viral diversity in hot springs of Pozzuoli, Italy, and characterization of a unique archaeal virus, Acidianus bottleshaped virus, from a new family, the Ampullaciridae. J. Virol. 79 (15) 9904-0011.

HARVEY K (2007) Healing Touch. Sawubona, January 2007, 75-76.

HELLMAN MJ and RAMSEY MS (2004) Analysis of hot mineral springs and associated deposits in Yellowstone National Park using ASTER and AVIRIS remote sensing. J. Volcanol. Geotherm. Res. 134 (1-2) 195-219.

HOFFMANN JRH (1979) Die Chemiese Samestelling van Warmwaterbronne in Suid- en Suidwes-Afrika. CSIR Report No. WAT 56A, Pretoria. $21 \mathrm{pp}$.

HOOLE RG (2001) The Development of Lilani Hot Spring: An Analysis of Socio-Economic and Environmental Impacts. Unpub. M.Sc. Dissertation, University of Natal, Pietermaritzburg, South Africa.

HUTTRER G W (2001) The status of geothermal power generation 1995-2000. Geothermics 30 1-27. Www.elsevier.com/locate/geothermics (Accessed 7 December 2006).

KRISTMANNSDOTTIR H and BJORNSSON O G (2003) Balneological prospects in Iceland using geothermal resources. Paper 055. Proc. Int. Geotherm. Conf. September 2003, Reykjavik, S03. 19-26.

IZUMIYAMA S, YAGITA K, FURUSHIMA-SHIMOGAWARAM ASAKURA T, KARASUNDANI T and ENDO T (2003) Occurrence and distribution of Naegleria species in thermal waters in Japan. J. Eukaryot Microbiol. 50 (1) 514.

KEMPSTER PL, VAN VLIET HR, LOOSER U, PARKER I, SILBERBAUER MJ and DU TOIT P (1996) Overview of Radioactivity in Water Sources: Uranium, Radium and Thorium. Institute for Water Quality Studies, Department of Water Affairs and Forestry, South Africa.

KENT LE (1946) The warm springs of Loubad, near Nylstroom, Transvaal. Trans. Royal Soc. South Afr. 31 (2) 151-168.

KENT LE (1948) Diatomaceous deposits in the Union of South Africa. Mem. Geol. Surv. S. Afr. 42 (11) 75-78; 81-84.

KENT LE (1949) The thermal waters of the Union of South Africa and South West Africa. Trans. Geol. Soc. S. Afr. 52 231-264.

KENT LE (1952) The Medicinal Springs of South Africa. Publication and Travel Department, South African Railways, Pretoria.

KENT LE (1969) The thermal waters in the Republic of South Africa. In: Proc. of Symp. II on Mineral and Thermal Waters of the World, $B$ - Overseas Countries, Vol 19, Report of the $23 \mathrm{rd}$ session of the Int. Geol. Conf., 1968, Academia, Prague. 143-164.

KENT LE and RUSSELL HD (1950) The warm spring on Buffelshoek, near Thabazimbi, Transvaal. Trans. Royal Soc. S. Afr. 32 161-175.

LABOUTKA M and VYLITA B (1983) Mineral and thermal waters of Western Bohemia, Geo. J. 7 (5) 403-411.

LAMOREAUX PE and TANNER JT (eds.) (2001) Springs and Bottled Waters of the World. Ancient History, Source, Occurrence, Quality and Use. Springer Verlag, Berlin.

LLOYD JW and HEATHCOTE JA (1985) Natural Inorganic Hydrochemistry in Relation to Groundwater. Clarendon Press, Oxford.

LUND J W (1996) Balneological use of thermal and mineral waters in the USA, Geotherm. 25 (1) 103-147. Elsevier Science, Ltd, Great Britain.

LUND J W (2000) Balneological use of thermal water in the USA. GHC Bulletin, September, 31-34.

LUND J W and FREESTON D H (2001) World-wide direct uses of geothermal energy 2000. Geotherm. 30 29-68.

MANDAL and SUZUKI KT (2002) Arsenic round the world: a review. Talanta 58 (1) 201-235.

MAZOR E and VERHAGEN BT (1983) Dissolved ions, stable and radioactive isotopes and noble gases in thermal waters of South Africa. J. Hydrol. 63 315-329.
MIYAMOTO H, JITSURONG S, SHIOTA R, MARUTA K, YOSHIDA $S$ and YABUUCHI E (1997) Molecular determination of infection source of a sporadic Legionella pneumonia case associated with a hot spring bath. Microbial. Immunol. 41 (3) 197-202.

MOCK JE (1993) Geothermal energy - the environmentally responsible energy technology for the 90s: A federal perspective. In: Proc. Geothermal Energy: The Environmentally Responsible Energy Technology for the Nineties. Berkeley, California, USA, 27-29 April 1993.

PENTECOST A, JONES B and RENAUT RW (2003) What is a hot spring? Can. J. Earth Sci. 40 (11) 1443-1446.

PETRACCIA L, LIBERATI G and MASCIULLO SG (2005) Water, mineral waters and health. Clin. Nutrit. 25 (3) 377-385.

PRESS F and SIEVER R (1986) Earth (4 ${ }^{\text {th }}$ edn.). WH Freeman and Co., New York.

RINDL MR (1916) The Medicinal Springs of South Africa (Supplement). S. Afr. J. Sci. 13 528-552.

RINDL MR (1918) The Medicinal Springs of South Africa (Supplement). S. Afr. J. Sci. 15 217-225.

RINDL MR (1928) The Medicinal Springs of South Africa (Supplement). S. Afr. J. Sci. 25 116-126.

RINDL MR (1930) The Medicinal Springs of South Africa (Supplement). S. Afr. J. Sci. 27 213-226.

RINDL MR (1931) The Medicinal Springs of South Africa (Supplement). S. Afr. J. Sci. 28 119-130.

RINDL MR (1932) The Medicinal Springs of South Africa (Supplement). S. Afr. J. Sci. 29 278-280.

RINDL MR (1934) The Medicinal Springs of South Africa (Supplement). S. Afr. J. Sci. 31 173-176.

RINDL MR and Ing D (1937) The Medicinal Springs of South Africa (Supplement). S. Afr. J. Sci. 33 254-257.

ROMERO L, ALOMSO H, CAMPANO P, FANFANI L, CIDU R, DADEA C, KEEGAN T, THORNTON I and FARAGO M (2003) Arsenic enrichment in waters and sediments of the Rio Loa (Second Region, Chile). Appl. Geochem. 18 (9) 1399-1416.

ROSE JG (1910) A new Cape thermal Chalybeate spring. S. Afr. J. Sci. $7202-203$.

SABA D S, NAJAF M E, MUSAZAI A M and TARAKI S A (2004) Geothermal energy in Afghanistan: Prospects and potential. http// www.mindfully.org/Energy/2004/Afghanistan-Geothermal Energylfeb04 (Accessed 10 May 2006).

SANNER B (2000) Baden-Baden, a famous thermal spa with a long history. GHC Bulletin, September, 16-22.

SHEVENELL L, GARSIDE L, AREHART G, VAN SOEST $M$ and KENNEDY BM (2002) Geothermal sampling of thermal and nonthermal waters in Nevada to evaluate the potential for resource utilization. GRC Trans. 2002.

SÖHNGE PG (1945) The geology of the Messina copper mines and surrounding country. Mem. Geol. Surv. S. Afr. 40 106-107; 122-127.

SOUTH AFRICAN BUREAU OF STANDARDS (SABS) (1999) Class 1 Potable Water Standards. SABS 241:1999, Pretoria, South Africa.

SAMSUDIN AR, HAMZAH U, RAHMAN RA, SIWAR C, JANI MF and OTHMAN R (1997) Thermal springs of Malaysia and their potential development. J. Asian Earth Sci. 15 275-289.

SUGITA Y, FUJII T, HAYASHI I, AOKI T, YOKOYAMA T, MORIMATSU M, FUKUMA T and TAKAMIYA Y (1999) Primary amebic meningoencephalis due to Naegleria fowleri: An autopsy case in Japan. Pathol. Int. 49 (5) 468-470.

TEMPERLEY BN (1975) The Welgevonden Fault Aquifer of the Central Transvaal and its Thermal Water. Groundwater Series No. 2, South African Geological Survey. Pretoria, South Africa.

USHER BH, PRETORIUS JA, DENNIS I, JOVANOVIC N, CLARKE S, CAVE L, TITUS R and XU Y (2004) Identification and Prioritisation of Groundwater Contaminants and Sources in South Africa's Urban Catchment. WRC Report No. 1326/1/04, Water Research Commission, Pretoria, South Africa.

VAN VUUREN K (1990) Die Warmwaterbronne van Suidwes-Kaapland: Hulle Verbreiding, Eienskappe en Benutting. B.A. Honours Dissertation, University of Stellenbosch. 
VIMMERSTEDT LJ (1998) Opportunities for Small Geothermal Projects: Rural power for Latin America, the Carribbean and the Philippines. Natural Renewable Energy Laboratory, Colorado, USA.

VISSER DJL (1989) The Geology of the Republics of South Africa, Transkei, Bophuthatswana, Venda and Ciskei and the Kingdoms of Lesotho and Swaziland (4th edn.). Department of Mineral and Energy Affairs, Pretoria, South Africa.

VON BACKSTRÖM JW (1962) Thermal springs on Driefontein 317 KR north of Naboomspruit, Potgietersrus District, Transvaal. Ann. Geol. Surv. S. Afr. 1 183-187. 